\title{
Microbiological Assessment of Indoor Air of Takalar County Hospital Wards in South Sulawesi, Indonesia
}

\author{
Muhammad Ikhtiar ${ }^{1}$, Herlina Alzad ${ }^{1}$, Swandari Paramita $^{2}$, Yadi $^{2, ~ *}$ \\ ${ }^{1}$ Faculty of Public Health, Universitas Muslim Indonesia, Makassar, Indonesia \\ ${ }^{2}$ Faculty of Medicine, Universitas Mulawarman, Samarinda, Indonesia
}

Email address:

dryadi02@yahoo.com (Yadi)

*Corresponding author

\section{To cite this article:}

Muhammad Ikhtiar, Herlina Alzad, Swandari Paramita, Yadi. Microbiological Assessment of Indoor Air of Takalar County Hospital Wards in South Sulawesi, Indonesia. Science Journal of Public Health. Vol. 5, No. 3, 2017, pp. 172-177. doi: 10.11648/j.sjph.20170503.13

Received: January 12, 2017; Accepted: February 20, 2017; Published: March 9, 2017

\begin{abstract}
Poor indoor air quality may lead to hospital acquired infection. Microbiological parameter is one of main standards of indoor air quality. The study objective was to investigate microbiological assessment of indoor air of different wards of Takalar County Hospital, South Sulawesi, Indonesia. Four wards were used for sample collection and these included third, second, first and VIP class ward. Room air temperature, humidity, lighting and number of visitor were also observed. Passive air sampling technique using open Petri dishes containing different culture media was employed. Blood agar plate was used for the bacteria, while Sabouraud dextrose agar plates were used for the fungi. Samplings were done twice daily, one in the morning and other in the afternoon. Isolates were identified according to standard methods. Results show that there was second class ward recorded the highest bacterial growth $\left(1,413 \mathrm{cfu} / \mathrm{m}^{3}\right.$ in the afternoon). The bacteria isolates were Bacillus sp, Enterobacter sp, Staphylococcus aureus, and Staphylococcus epidermidis. Staphylococcus aureus was the predominantly isolated bacterium. For the conclusion, from the reduction noticed in the morning samples, stringent measures such as proper disinfection and regular cleaning, restriction of patient relatives' movement in and out the wards need to be enforced so as to improve the quality of indoor air of hospital wards.
\end{abstract}

Keywords: Microbiological Assessment, Indoor Air, Hospital Wards

\section{Introduction}

Communicable diseases are still the most prevalent one in Indonesia. The patients prefer medicine for the treatment of their conditions because of the high cure rate achieved with those. While in the hospital, the patients aggregate the various causative agents in one place, placing other patients, visitors to the hospital, and health-care workers at risk [1].

Patients are primarily admitted into hospital wards for proper management of their ailments than the one they were admitted for. These are called hospital associated infections (nosocomial infections) which can result from contact with a carrier directly or indirectly through inanimate objects or air. The complex hospital environment requires special attention so as to ensure healthy indoor air quality to protect patients and healthcare workers from hospital-acquired (nosocomial) infections and occupational diseases [2].
Hospitals are increasingly becoming epicenters of outbreaks of certain communicable diseases, including tuberculosis, diarrheal, and viral hemorrhagic. This public health problem is further exacerbated by the increasing resistance of the hospital-acquired infections to common antibiotics. Several of the those are airborne, and good ventilation is recognized as one of the most effective ways of reducing the risk of transmission of airborne infections in here [3].

The quality of indoor air in terms of microbial contamination in a given time period is said to be determined by the quality of air entering the space, the number of occupants, their physical activities and resultant aerosol generation, human traffic and the degree of ventilation. Airborne microorganisms can originate not only from 
humans (including patients), but can also be spawned by various inside hospital characteristics and outside environmental sources. Air pollution is one of the most severe problems of our time. Several airborne diseases have been related to the indoor air quality. Air quality is a significant issue in healthcare. Healthcare facilities have to pay particular care and attention to indoor air concerns due to the presence of microorganism that may cause nosocomial infection. People with pre-existing health problems who are going through treatment and those who may have depressed immune systems are very susceptible to air exposures [4].

The Center for Disease Control and Prevention of U. S. estimates that more than two million patients acquire infections per year in U. S. hospitals, while they are hospitalized for other health problems, and that 88,000 die as a direct or indirect result [5]. In USA, two million patients are affected by nosocomial infections attributed to air pollutions annually, of which 90 thousand people die due to the infections. Thus, the financial burden of 5 to 10 billion dollars is being imposed to the economy of this country at each year [6].

The hospital environment thus represents a congenial situation where microorganisms and susceptible patients are together indoors. For this reason, hospital environmental control procedures can be an effective support in reducing nosocomial infections. Measures often taken in preventing nosocomial infections include effective use of antiseptics, disinfectants, adequate cleaning, sterilization and isolation of patients with highly infectious diseases. However, less attention is paid to indoor air has been a probable contributing factor to nosocomial infections [7].

Hospital buildings may be regarded as dynamic environments affected by season, weather conditions, ventilation system design and operation, intrusion of moisture, outdoor microbial load and the number of occupants, visitors and human activities. Air quality is of great importance in hospitals. It is necessary to utilize the highest quality standards for clean air in order to provide the medical services and protect the health of patients and medical staff against infectious diseases, especially airborne ones. Air quality is affected by a range of chemical and infectious contaminants which may emerge due to different factors including the diversity of services and activities, the patients especially with infectious diseases, and using various chemicals such as anesthetic drugs, pharmaceutical products, laboratory chemicals, cleaning agents and disinfectants. The mentioned factors can affect the duration of the patients treatment and the safety and health of healthcare providers. As a result, it is of great importance to observe the highest standards for the air quality, especially microbiological standards [2].

\section{Method}

\subsection{Study Area}

The study was conducted on April 2016 in Takalar County
Hospital, This hospital is a tertiary health institution and referral hospital in Takalar Regency, located in the southern part of South Sulawesi, Indonesia. It has 228 bed capacity and a total of more than 250 staffs of both supportive and professional. It provides services for approximately 3,000 inpatient and 50,000 outpatient attendances a year coming from the catchment population of Takalar Regency about 250,000 people. Four wards were used for sample collection and these included third, second, first and VIP class ward.

\subsection{Sampling Procedures}

Bacteria and fungi measurement were made by passive air sampling technique: the settle plate method using $9 \mathrm{~cm}$ diameter Petri dishes. Triplicate samples for each culture medium were collected to ensure sampling accuracy. Three plates of each medium were distributed at different parts of wards examined. Samples were collected twice a day at 8.00 am and $12.00 \mathrm{pm}$. The sampling height which approximated the human breathing zone was $1 \mathrm{~m}$ above the floor and at the center of the room. The plates containing the culture media, blood agar plate were used for the bacteria, while Sabouraud dextrose agar plates were used for the fungi. To obtain the appropriate surface density for counting and to determine the load with respect to time of exposure, the sampling times were set at 60 minutes. After exposure, the sample were covered and taken immediately to the Microbiology Laboratory in Universitas Muslim Indonesia for incubation. To avoid self-contamination of agar plate during air sampling, sterile gloves, mouth masks and protective gown were worn, and before it was used the agar plate was checked visually for any microbial growth. The blood agar plates were incubated at $37^{\circ} \mathrm{C}$ for 48 hours while the Sabouraud dextrose agar plates were incubated for 3-5 days at $28^{\circ} \mathrm{C}$. After incubation, the bacterial and fungal colonies were counted and calculated to express as colony forming unit $/ \mathrm{m}^{3}$ $\left(\mathrm{cfu} / \mathrm{m}^{3}\right)$.

The identification of the isolates was done according to standard procedures [7]. The isolated bacteria and fungi identified by Gram's stain and microscope morphology (lacto-phenol cotton blue). Bacterial phenotyping was based primarily on morphology and Gram-staining. Bacteria were grouped into morphological groups as Gram-positive cocci, Gram-negative cocci, Gram-positive rods and Gram-negative rods according to their microscopic morphology. Identification of filamentous fungi was carried out on material mounted in lactophenol blue and achieved through morphological characteristics.

Room temperature was measured by thermometer. Room humidity was measured by hygrometer. Room lighting was measured by digital lux meter. Thermometer, hygrometer and lux meter were put in the middle of the ward, one meter high from the ground. The number of visitor was counted twice a day at 8.00 am and $12.00 \mathrm{pm}$, by taking into consideration the variation of density of occupant and environmental factors. 


\section{Result}

This study therefore was aimed at investigating the quality of indoor air of different wards of Takalar County Hospital, South Sulawesi, Indonesia. It will also provide baseline information on the microbiological assessment of indoor air which before now was not available. Air samples were taken to characterize airborne microbial concentrations in four different hospital wards.

Table 1 show highest colony counts are in second ward class. The maximum level for microbial index number of air microbial in hospital ward is $200-500 \mathrm{CFU} / \mathrm{m}^{3}$. Table 2 shows frequently microbial found in Takalar county hospital ward are Bacillus sp and Staphylococcus aureus, meanwhile rare microbial found are Enterobacter sp and Staphylococcus epidermidis. Table 3 shows highest air temperature is in third class ward $\left(32^{\circ} \mathrm{C}\right)$; meanwhile lowest air temperature is in first class ward $\left(30.2^{\circ} \mathrm{C}\right)$. Table 4 shows highest air humidity level is in VIP class ward $(76 \%)$, meanwhile lowest air humidity is in third class ward $(68 \%)$. Table 5 shows highest room lighting is in second class ward (638 lux), meanwhile lowest room lighting is in third class ward (100 lux ). Table 6 shows highest number of visitor is in third class ward (18 people), meanwhile the lowest number of visitor is in second dan VIP class ward.

Table 1. Result of Air Microbial using Petri dish in Takalar County Hospital Ward.

\begin{tabular}{|c|c|c|c|c|c|c|}
\hline \multirow[t]{2}{*}{ No } & \multirow{2}{*}{$\begin{array}{l}\text { Ward } \\
\text { Class }\end{array}$} & \multicolumn{2}{|c|}{ Colony Counts (CFU) } & \multicolumn{2}{|c|}{$\begin{array}{l}\text { Microbial Index } \\
\text { Number }\left(\mathrm{CFU} / \mathrm{m}^{3}\right)\end{array}$} & \multirow[t]{2}{*}{ Note } \\
\hline & & Morning & Afternoon & Morning & Afternoon & \\
\hline 1 & $\begin{array}{l}\text { Third } \\
\text { Class }\end{array}$ & 34 & 70 & 400 & 824 & NQ \\
\hline 2 & $\begin{array}{l}\text { Second } \\
\text { Class }\end{array}$ & 36 & 120 & 424 & 1413 & NQ \\
\hline 3 & $\begin{array}{l}\text { First } \\
\text { Class }\end{array}$ & 9 & 36 & 106 & 424 & Q \\
\hline 4 & $\begin{array}{l}\text { VIP } \\
\text { Class }\end{array}$ & 12 & 20 & 141 & 236 & Q \\
\hline
\end{tabular}

Note:

NQ: Not Qualified

Q: Qualified

Table 2. Result of Air Microbial Identification in Takalar County Hospital Ward.

\begin{tabular}{|c|c|c|c|}
\hline \multirow{2}{*}{ No } & \multirow{2}{*}{$\begin{array}{l}\text { Ward } \\
\text { Class }\end{array}$} & \multicolumn{2}{|l|}{ Microbial Identification } \\
\hline & & Morning & Afternoon \\
\hline \multirow{3}{*}{1} & \multirow{3}{*}{$\begin{array}{l}\text { Third } \\
\text { Class }\end{array}$} & Bacillus sp & Bacillus sp \\
\hline & & Staphylococcus aureus & Staphylococcus aureus \\
\hline & & Staphylococcus epidermidis & Staphylococcus epidermidis \\
\hline \multirow{4}{*}{2} & \multirow{4}{*}{$\begin{array}{l}\text { Second } \\
\text { Class }\end{array}$} & Bacillus sp & Bacillus sp \\
\hline & & Staphylococcus aureus & Staphylococcus aureus \\
\hline & & & Enterobacter sp \\
\hline & & & Mold/fungi \\
\hline \multirow{3}{*}{3} & \multirow{3}{*}{$\begin{array}{l}\text { First } \\
\text { Class }\end{array}$} & Bacillus sp & Bacillus sp \\
\hline & & Staphylococcus aureus & Staphylococcus aureus \\
\hline & & Mold/fungi & \\
\hline \multirow{2}{*}{4} & VIP & Bacillus sp & Bacillus sp \\
\hline & Class & Staphylococcus aureus & Staphylococcus aureus \\
\hline
\end{tabular}

Table 3. Result of Air Temperature in Takalar County Hospital Ward.

\begin{tabular}{lllll}
\hline \multirow{2}{*}{ No } & \multirow{2}{*}{ Class Ward } & \multicolumn{2}{c}{ Temperature $\left({ }^{\circ} \mathbf{C}\right)$} & \multirow{2}{*}{ Note } \\
\cline { 3 - 4 } & & Morning & Afternoon & \\
\hline 1 & Third Class & 30.8 & 32.9 & NQ \\
2 & Second Class & 30.7 & 30.3 & NQ \\
3 & First Class & 28.8 & 31.5 & NQ \\
4 & VIP Class & 29.5 & 32.5 & NQ \\
\hline
\end{tabular}

Note:

NQ: Not Qualified

Q: Qualified

Table 4. Result of Air Humidity in Takalar County Hospital Ward.

\begin{tabular}{lllll}
\hline \multirow{2}{*}{ No } & \multirow{2}{*}{ Class Ward } & \multicolumn{2}{l}{ Humidity (\%) } & \multirow{2}{*}{ Note } \\
\cline { 3 - 4 } & & Morning & Afternoon & \\
\hline 1 & Third Class & 64.4 & 71.6 & NQ \\
2 & Second Class & 69.6 & 70.5 & NQ \\
3 & First Class & 75.1 & 76.5 & NQ \\
4 & VIP Class & 75 & 77.1 & NQ \\
\hline
\end{tabular}

Note:

NQ: Not Qualified

Q: Qualified

Table 5. Result of Lighting Intensity in Takalar County Hospital Ward.

\begin{tabular}{lllll}
\hline \multirow{2}{*}{ No } & \multirow{2}{*}{ Wards Class } & \multicolumn{2}{l}{ Lighting $(\boldsymbol{L u} \boldsymbol{x})$} & \multirow{2}{*}{ Note } \\
\cline { 3 - 4 } & & Morning & Afternoon & \\
\hline 1 & Third Class & 87 & 112 & Q \\
2 & Second Class & 960 & 315 & NQ \\
3 & First Class & 152 & 232 & Q \\
4 & VIP Class & 96 & 110 & Q \\
\hline
\end{tabular}

Note:

NQ: Not Qualified

Q: Qualified

Table 6. Result of Visitor Number in Takalar County Hospital Ward.

\begin{tabular}{lllll}
\hline No & Ward Class & Number of Visitor & Room Area $\left.\mathbf{( m}^{\mathbf{2}}\right)$ & Note \\
\hline 1 & Third Class & 18 & 7.5 & NQ \\
2 & Second Class & 8 & 4.5 & NQ \\
3 & First Class & 13 & 4.5 & NQ \\
4 & VIP Class & 8 & 4.5 & NQ \\
Total & 47 & 21 & NQ \\
\hline \multicolumn{2}{l}{ Note: } & & & \\
NQ: Not Qualified & & & \\
Q: Qualified &
\end{tabular}

\section{Discussion}

The result of this study showed microbiological assessment of indoor air of different wards of Takalar County Hospital, South Sulawesi, Indonesia. The concentrations of bacteria and fungi aerosols estimated with the use of the settle plate method, ranged between 106-1413 CFU $/ \mathrm{m}^{3}$. The study shows frequently microbial found in Takalar county hospital ward are Bacillus sp and Staphylococcus aureus, meanwhile rare microbial found are Enterobacter sp and Staphylococcus epidermidis. The study revealed that third class wards recorded the highest indoor airborne bacteria population. The result does not meet the government standard in Indonesia about Environmental Health Standard of Hospital. The maximum level for microbial index number 
of air microbial in hospital ward is 200-500 CFU $/ \mathrm{m}^{3}$. Meanwhile, the result of air microbial condition for first and VIP class does meet the government standard [1].

Hospital related infections have been linked with many factors among which are the microbial qualities of the indoor air of different wards of each hospital. There is no uniform international standard available on levels and acceptable maximum bioaerosol loads. Different countries have different standards [8]. The work conducted by a WHO expert group on assessment of health risks of biological agents in indoor environments suggested that total microbial load should not exceed $1000 \mathrm{CFU} / \mathrm{m}^{3}$. If higher than this, the environment is considered as contaminated [9]. The American Conference of Governmental Industrial Hygienists (ACGIH) recommended that the optimal level of bacterial counts or fungal counts in indoor air should be less than 500 $\mathrm{cfu} / \mathrm{m}^{3}$. The high bacterial count or fungal count in indoor air of general workplaces was an indication of poor ventilation and congestion [10]. However, World Health Organization suggested that the microbial counts in the general offices should be less than $300 \mathrm{cfu} / \mathrm{m}^{3}$ and for individuals or patients with immune-suppression, it should be less than $100 \mathrm{cfu} / \mathrm{m}^{3}$ [11].

The study showed the presence of different species of bacteria and fungi in the ambient air of all the study sites. The bacteria and fungi cultured from the study sites are the same as the ones cultured in the other studies. The cultured bacteria are mostly pathogenic and have been implicated in many nosocomial infections [3]. Staphylococcus aureus as the most frequently isolated bacterium from this study has been incriminated in various diseases such as post operative infections, urinary tract infections, skin infections, respiratory infections and food poisoning [7]. The isolation rate of bacterial species indicated a similar pattern among the different hospital services. Airborne Gram-positive cocci were the most frequent phenotype (88\%) detected from the measured bacterial air population in all indoor environments. The predominant isolated genera included Gram-positive cocci such as Staphylococcus (including Staphylococcus aureus and Staphylococcus epidermidis) [2].

Bacillus sp. are spore forming organisms that can survive for longer period of time and can cause serious medical problems, hence proper program for eliminating it must be put in place. Fungi were detected in the ambient air of all the study sites; their medical importance is not only in their roles in nosocomial infections but also in their actions as allergens and toxins. Fungi such as the Penicillium sp., Rhizopus sp., and Aspergillus sp. cultured from all the study sites are prolific sources of allergens that can trigger off the asthmatic attack and other allergic reactions [3].

Bio aerosol is an important biological component in the hospital environments. Infectious agents can be carried as airborne particles or droplet nuclei then spread quickly to people. Most infections are due to inhalation of droplet nuclei from 1 to 5 micron range. The bacteria can settle in the lungs and grow causing an infection. As outlined by other study the number of occupants, visitors and human activities are important factors that might influence microbial growth in hospital settings [2]. The types and number of airborne bacteria and fungi in the study sites seem to be influenced by the type of activities carried out in the study site; the type and number of patients at the site, the level of ventilation, and the level of hygiene of the study site [3]. The microbial counts in indoor air depends on several variables, such as velocity, humidity, temperature, ventilation, number of occupants, people's activities, a concentration of particulate matter or dust, and the outdoor air quality [12].

Many of these isolates (bacteria) are shown to be resistant to common antiseptics used in hospitals. Organisms that are often associated with hospital acquired infections are Staphylococcus aureus, Micrococcus sp., Pseudomonas sp., Proteus sp., Escherichia coli, Enterobacter sp., Bacillus cereus, Cladosporium sp., and Aspergillus sp.. Regular surveillance, cleaning and restriction of patients' relative might be among the strict measures necessary to reduce or totally eliminate the microbial load of indoor air of this hospital wards. Cleaning of local exhaust fans, fans and air conditioners, and managing everything that blocked the natural air from the windows and doors could improve the ward ventilation and reduce the microbial counts in indoor air [7].

The study shows air temperature ranged between 30.2$32^{\circ} \mathrm{C}$. The result of all class ward do not meet government standard in Indonesia about Environmental Health Standard of Hospital. The standard for air temperature is $22-24^{\circ} \mathrm{C}$. The study shows air humidity ranged between $68-76 \%$. The result of all class ward do not meet government standard in Indonesia about Environmental Health Standard of Hospital. The standard for air humidity is $45-60 \%$. The study shows room lighting ranged between 100-638 lux. The result of all class meet government standard in Indonesia about Environmental Health Standard of Hospital, except for second class ward (638lux). The standard for room lighting is 100-200 lux. The study shows number of visitor ranged between 8-18 people. The result of all class ward do not meet government standard in Indonesia. The standard for minimum room area $8 \mathrm{~m}^{2}$ are for not more than 2 people [1].

Hospital buildings are designed, constructed and managed to provide a healthy and comfortable environment for patients, staff and carers. The air temperature, humidity and airflow in the hospital provide a comfortable environment for patients, staff and carers. Airflow minimizes the risk of transmission of airborne pathogens from infected patients and minimizes risks to susceptible staff, patients and carers. Sufficient lighting is provided during all working hours to allow safe movement of staff, patients and carers, and normal undertaking of medical activities. Buildings are designed and activities are organized so as to minimize the spread of contamination by the movement of patients, staff and carers, equipment, supplies and contaminated items, including health-care waste, and to facilitate hygiene. Hospital settings are built, furnished and equipped with materials that minimize infectious disease transmission and facilitate cleaning. Sufficient space is provided for people in 
wheelchairs, as well as to minimize infectious disease transmission [5].

Guidline for hospital ventilation should be followed by locating and constructing buildings that use designs and materials that produce the best indoor conditions, taking into account the local climate and prevailing winds. The effective use of blinds, opening and closing of doors and windows, planting of suitable vegetation around the building and other operational measures can help optimize indoor conditions. In addition to basic construction and operation measures, heating, ventilation and airconditioning, or filters may be required for specific areas or activities of the hospital setting. If heating, ventilation and air-conditioning, or filters are used, they should be maintained regularly to ensure their continued effectiveness [13].

Filters should be inspected regularly and cleaned or changed as required, because biofilms may build up and become breeding places for microorganisms. Natural light may be sufficient in outpatient settings that operate only during the day. However, some form of lighting should be available for night-time emergencies. Given the size and complexity of the hospital setting and the resources available, activities should be organized in zones, with the flow of people, equipment and materials managed so as to minimize movements from "dirty" to "clean" zones [5].

Keeping the body at the normal temperature is important for comfort and health. Generally speaking, a healthy person feels most comfortable in an environment where the body can easily maintain a thermal balance with the surrounding air. Both over-cooled and over-heated indoor temperatures will bring adverse health effects to occupants. According to American Society of Heating, Refrigerating and Airconditioning Engineers organization (ASHRAE), the thermal comfort indexes of dry and wet temperature are $25.5-22.5^{\circ} \mathrm{C}$, respectively and the relative humidity is less than 70\% [6].

High or low relative humidity $(\mathrm{RH} \%)$ can cause discomfort among occupants. Low air humidity affects comfort and health, and when the relative air humidity indoor drops, respiratory problems increase. High relative air humidity may contribute to water condensation and microbial growth, indirectly causing sickness building syndrome. Low relative air humidity or dry air has also been shown to cause dry and itchy skin, fatigue, feeling of illness and sickness. The risk of bacteria and virus attacks is normally higher in environments with a high $\mathrm{RH} \%$, but with particles (dust) in the air, even dry environments may represent a health hazard. The dry particle mass may cause an imbalance in the mucous membrane humidity, with resulting irritation [14].

\section{Conclusion}

In conclusion, all wards that were included in the study were contaminated with bacteria and fungi. The high bacteria and fungi concentrations of air obtained in this study might be potential risk factors for spread of nosocomial infection in Takalar County Hospital Wards. Thus, immediate interventions is needed to control those environmental factors which favor the growth and multiplication of microbes, and the hospital needs to increase the number of wards to make them sufficient for the inpatients that come from catchment area. It is also vital to control visitors and students in and out of the wards. Moreover, it is advisable that strict measures be put in place to check the increasing microbial load in the hospital environment.

Furthermore, microbiological survey data should be used to clearly define specific air quality guidelines for controlled environments in hospital settings. The health hazards posed by the type and count of the bacteria and fungi in the ambient air of the study sites call for corrective actions. Whereas little actions can be taken to reduce the source of the microorganisms in patients, there are however many corrective actions that can be applied to reduce the ambient levels of the bacteria and fungi. These actions include improving the hygiene levels in the study sites.

\section{References}

[1] Ministry of Health Republic of Indonesia (MOHRI). (2004). Decision of Ministry of Health Republic of Indonesia 1204/2004 on the Requirement of the Hospital Environment. Ministry of Health Republic of Indonesia. Jakarta.

[2] Verde SC, Almeida SM, Matos J, Gurreiro D, Meneses M, Faria T, Botelho D, Santos M, Viegas C. (2015). Microbiological assessment of indoor air quality at different hospital sites. Research in Microbiology. 1-7.

[3] Emuren K, Ordinioha B. (2016). Microbiological assessment of indoor air quality at different sites of a tertiary hospital in South-South Nigeria. Port Harcourt Medical Journal. 10: 79-84.

[4] Fekadu S, Getachewu B. (2015). Microbiological Assessment of Indoor Air of Teaching Hospital Wards: A Case of Jimma University Specialized Hospital. Ethiopian Journal of Health Sciences. 25 (2): 117-122.

[5] World Health Organization (WHO). (2010). WHO Guidelines for Indoor Air Quality: Selected Pollutants. World Health Organization. Geneva.

[6] Shokri S, Nikpey A, Varyani AS. (2016). Evaluation of hospital wards indoor air quality: the particles concentration. Journal of Air Pollution and Health. 1 (3): 205-214.

[7] Awosika SA, Olajubu FA, Amusa NA. (2012). Microbiological assessment of indoor air of a teaching hospital in Nigeria. Asian Pacific Journal of Tropical Biomedicine. 2 (6): 465-468.

[8] Nevalainen A, Morawaska L. (2009). Biological Agents in Indoor Environments. Assessment of Health Risks. Work conducted by a WHO Expert Group between 2000-2003. World Health Organization. Geneva.

[9] National Institute for Occupational Safety and Health (NIOSH). (1989). Indoor Air Quality: Selected References. Ohio.

[10] European Communities Commission (ECC). (1993). Indoor Air Quality and Its Impact On Man. Report No. 12: Biological Particles in Indoor Environments. Luxembourg. 
[11] Environmental Protection Agency (EPA). (2010). SOP Sampling and Characterization of Bioaerosol in Indoor Air. Environmental Health and Engineering. United States of America.

[12] Luksamijarulkul P, Aiempradit N, Vatanasomboon P. (2014). Microbial contamination on used surgical masks among health personnel and microbial air quality in their working wards: a hospital in Bangkok. Oman Medical Journal. 29 (5): 346-350.
[13] World Health Organization (WHO). (2008). Essential environmental health standards in health care. Editors: John Adams, Jaime Bartram and Yves Chartier. World Health Organization. Geneva.

[14] Aljeesh Y, Madhoun WA, Shamh IA, Arcaya M. (2016). Assessment of indoor air quality in neonatal intensive care unit in government hospitals in Gaza Strip, Palestine. Public Health Research. 6 (1): 24-30. 